Abstract A5.8 Table 1

\begin{tabular}{|c|c|c|c|c|c|c|c|c|c|c|}
\hline & $\begin{array}{l}\text { Mean DAS28 } \\
\text { at baseline }\end{array}$ & $\begin{array}{l}\text { Mean DAS28 } \\
\text { at } 3 \text { months }\end{array}$ & $\begin{array}{l}\text { Mean DAS28 } \\
\text { at } 6 \text { months }\end{array}$ & $\begin{array}{l}\text { Goodeular response } \\
\text { at } 3 \text { months }\end{array}$ & $\begin{array}{l}\text { Goodeular response } \\
\text { at } 6 \text { months }\end{array}$ & $\begin{array}{l}\text { DAS28 < } 2.6 \\
\text { at } 3 \text { monts }\end{array}$ & $\begin{array}{l}\text { DAS28 < } 2.6 \\
\text { at } 6 \text { months }\end{array}$ & $\begin{array}{l}\text { HAQ } \\
\text { at baseline }\end{array}$ & $\begin{array}{l}\text { HAQ } \\
\text { at } 3 \text { months }\end{array}$ & $\begin{array}{l}\text { HAO } \\
\text { at } 6 \text { months }\end{array}$ \\
\hline+ & $5.73 \pm 1.24$ & $3.38 \pm 1.30$ & $4.13 \pm 1.83$ & $90.5 \%$ & $65.2 \%$ & $18.2 \%$ & $17.4 \%$ & $1.81 \pm 0.77$ & $1.00 \pm 0.57$ & $1.2 \pm 0.74$ \\
\hline $\mathrm{RF}-$ & $5.52 \pm 1.61$ & $3.72 \pm 0.93$ & $4.22 \pm 1.23$ & $83.3 \%$ & $57.1 \%$ & $14.3 \%$ & $14.3 \%$ & $1.57 \pm 0.78$ & $0.83 \pm 0.56$ & $0.95 \pm 0.54$ \\
\hline
\end{tabular}

Objective To evaluate the efficacy of RTX in our series of refractory seronegative and seropositive RA.

Materials and Methods Baseline characteristics and disease activity markers at baseline, and after 3 and 6 months of treatment with RTX $(1 \mathrm{~g} \times 2$ weeks), were collected in 33 patients. A descriptive study was made; and the relations between variables were analysed statistically.

Results The mean age was $52.06 \pm 12.01$ years, $75.8 \%$ female, $78.8 \%$ RF positive. The mean duration of illness was $7.70 \pm 4.47$ years. Thirty two patients (97\%) had failed at least to one TNF antagonist. Most of the patients (84.8\% 9) received RTX with methotrexate.

The mean DAS28 at baseline was $5.7 \pm 1.30$; at 3 months decreased to $3.4 \pm 1.22$, and at 6 months to $4.15 \pm 1.69(p<0.0005)$.

At 3 months, 88.9\% reached good eular response, and $63.3 \%$ at 6 months. Remission was obtained in $17.2 \%$ at 3 months and in $16.7 \%$ at 6 months.

It was also noted improvement in baseline $\mathrm{HAQ}$, after 3 and 6 months (from $1.75 \pm 0.767$ to $0.96 \pm 0.56$ and $1.24 \pm 0.70$ respectively).

No significant differences were found between decreases in DAS 28 at 3 and 6 months compared to baseline between RF seronegative and seropositive patients, neither in good eular response, remission percentages or HAQ improvement. The data are shown in the table.

Discussion The efficacy and safety of RTX has been proved in several clinical trials.

The presence of RF, low baseline functional disability and no more than one previous anti-TNF are predictors of good response to RTX, as has been recently published.

Response rates in seronegative RA are slightly lower, although higher than placebo, as described in other publications.

In conclussion, the experience of RTX treatment in our patients with seronegative RA is positive, in terms of efficacy, due to the action on $\mathrm{B}$ cells and their different roles, with no significant differences comparing to seropositive RA.

\section{A5.9 VALUES OF B LYMPHOCYTE SUBPOPULATIONS (HEALTHY POPULATION) USING FLOW CYTOMETRY A STARTING POINT FOR ANY STUDY}

doi:10.1136/annrheumdis-2013-203219.9

A Munoz, R Hernández, J Uceda, M León, F Gallo, R Martínez, S Rodríguez, ML Velloso, N Cid, P González, L Mayordomo, E Rejón, JL Marenco. Rheumatology Unit, Valme University Hospital, Seville, Spain

Background Flow cytometry is a widely used technique nowadays for the determination of cell subpopulations in the study of autoimmune, infectious and tumoral diseases.

Our goal is to study the means and medians of B lymphocyte subpopulations in healthy population, to thereby have reference limits with which being able to compare when carrying out studies in population with autoimmune diseases.

Methods We studied 50 healthy patients. Male/female: 25/25. Age: 18-65 years. Previously, it was checked that none of these patients had any autoimmune diseases nor any other disease or condition causing lymphopenia or lymphocytosis. The fluorochromes used were: CD3, CD19, CD38, CD27 and IgD.

Results

\section{Abstract A5.9 Table 1}

\begin{tabular}{llll}
\hline Subpopulations & Mean & Typical deviation & Median \\
\hline Naive & 70.46 & 8.06 & 73.70 \\
DN & 4.05 & 2.08 & 4.66 \\
Unswitched Memory & 9.65 & 5.33 & 10.05 \\
switched Memory & 11.38 & 4.62 & 11.00 \\
Bm1 & 7.82 & 9.29 & 5.10 \\
Bm2 & 73.14 & 10.71 & 73.05 \\
PreGC & 2.90 & 1.61 & 2.89 \\
Bm3 + 4 & 0.56 & 0.53 & 0.44 \\
Late Bm5 & 3.17 & 2.74 & 2.50 \\
Early Bm5 & 9.12 & 4.93 & 9.21 \\
\hline
\end{tabular}

Conclusions Knowing the mean, medians and standard deviations of the B lymphocyte subpopulations subsets is important in helping to compare these results with those obtained in studies of patients with autoimmune diseases.

In most cases, conclusions drawn after the study with flow cytometry are based on knowing how these subpopulations vary with respect to healthy people in order to draw conclusions about what subpopulations are involved the most in the pathogenesis of the disease.

We believe, therefore, important to deepen in studies of this kind in order to clarify more situations of normality in the world of flow cytometry: a technique that is increasingly taking more importance in the understanding of autoimmune diseases.

\section{A5.10 $\triangle$ 4BAFF ALTERNATIVE SPLICING IS REGULATED BY IFN- $\gamma$ AND SC35 PROTEIN}

doi:10.1136/annrheumdis-2013-203219.10

'Gabriel J Tobón, '2Laurent Corcos, 'Laëtitia Le Pottier, ${ }^{2} G$ wendal Dujardin, 'Pierre Youinou, 'Jacques-Olivier Pers. 'EA2216 "Immunology \& Pathology"; 'INSERM, UMR1078, Brest University and European University of Brittany, Brest, France

Background The B-cell activating factor (BAFF) is a potent survival factor involved in the pathogenesis of autoimmune diseases. Recently, we reported the discovery of a new transcript for BAFF, $\triangle 4 \mathrm{BAFF}$ - lacking exon 4 -, which is mainly detected in autoimmune diseases and acts as a transcription factor for its own gene. However, the mechanisms implicated in $\triangle 4 B A F F$ induction and upregulation are unknown. In this study we analysed the induction and regulation of $\triangle 4 B A F F$.

Materials and Methods First, to study the alternative splicing of $B A F F$ exon 4, we transfected a minigene construct, centred on exon 4, into RAMOS B cells. To determine the proteins implicated in exon 4 inclusion/exclusion, we co-transfected the minigene together with each of the plasmids coding for the main splicing proteins 